\title{
Six-sigma derivatives: A case study
}

\section{Pardeep Rana ${ }^{a^{*}}$ and Prabhakar Kaushik ${ }^{a}$}

${ }^{a}$ Mechanical Engineering Department, University Institute of Engineering \& Technology, Maharshi Dayanand University, Rohtak, Haryana, India

\begin{tabular}{l}
\hline C H R O N I C L E \\
\hline Article history: \\
Received: March 23, 2018 \\
Received in revised format: March \\
23, 2018 \\
Accepted: June 7, 2018 \\
Available online: \\
June 8, 2018 \\
\hline Keywords: \\
Productivity Improvement \\
Six-Sigma \\
DMAIC \\
Problem Solving \\
Process Capability
\end{tabular}

\section{A B S T R A C T}

Nowadays, automobile industries are facing huge competition as the sector is expanding and ameliorating day by day. All organizations are thriving to attain top position by increasing their productivity. Productivity improvement is a function of eliminating rejection problem and improving system. To excel and improve the organizational efficiency a complete focus on finding root causes and eliminating factors responsible is needed. In industries, hurdles are associated with all operations. The existing study is about problem solving in a die-casting industry manufacturing alternator bracket. The authors explain the use of different statistical quality tools with the help of Minitab software to analyze root cause for enhancing the low productivity level. The streaming explanation of methodology can be useful for the organization of similar profile towards productivity improvement.

\section{Introduction}

Six-Sigma is a very famous tool among industrial engineers especially used for problem solving in manufacturing environment (Edgeman \& Dugan, 2008; Ho, 2010; Srinivasan et al., 2016; Falcón et al., 2012; Sharma, 2012). Various case studies have been reported till date that show the successful implementation of DMAIC methodology for productivity enhancement (Kaushik et al., 2017; Kaushik et al., 2016; Kaushik \& Mittal, 2015b; Kaushik, et al. 2016). Other than Six-Sigma there are various other tools available such as advance product quality planning (Mittal et al., 2010; Mittal et al., 2010; Mittal et al., 2011; Mittal et al., 2012), Business process re-engineering (Mittal et al., 2016), Quality council (Mittal \& Prajapati, 2014), Total quality management (Kaushik \& Mittal, 2015a; Sharma, 2013; Sharma, 2017b; Sharma, 2017a), Quality function deployment (Mittal \& Kaushik, 2011), Fuzzy MADM (Mittal et al., 2017b; Mittal et al., 2016), Operations research tools (Mittal et al., 2017; Mittal et al.. 2017a) etc., but six-sigma has proven itself as the most successful tool among manufacturing environment. The present study was performed at a die-casting industry in Gurgaon, Haryana, India. The industry is a house of built in technology and developing cutting edge die-casting products for major Overall Equipment Manufacturing (OEMs) worldwide. Industry was facing continuously low productivity levels and therefore 
immediate attention was needed in form of a quality management project. The part under consideration was an alternator. Alternator is an electrical device which converts mechanical energy into electrical energy. These are used in various places, but industry produces the alternators to be used in automobiles only. Various components used in assembly of the alternator are: Front bracket, back bracket, stator, rotor, rectifier diode, voltage regulator, fan, pulley, bearing etc.

Of the various components listed above, the present study focuses on bracket. There are two brackets used in the alternator. One is placed at front side and another one is on the back side of the alternator. The main purpose of the bracket in alternator is holding all the components of an alternator. The brackets of the alternator are manufactured with the help of the casting process. The size of the brackets depends on the alternator size and design as per as requirement of the customers. In present case, the alternator bracket in consideration is manufactured using aluminum alloy ADC-12. The organization was facing continuous quality related complaints from one of its elite customer which was due to mounting lug broken. In a recent complaint, seven pieces of M10 mounting lug broken were found in one lot of alternators. Therefore, a Six-Sigma project was initiated for improving the quality and achieve customer satisfaction.

\section{Implementation of Six-Sigma DMAIC Methodology}

Sigma is a measure of standard deviation and Six-Sigma corresponds to deviation of the order of 3.4 Defective Parts per Million Opportunities (DPMO). It follows a simple Define-Measure-Analyze-Improve-Control (DMAIC) methodology. A cross functional team was formed which consist 8 members from various functional areas within the organization. Various phases followed during the project are as follows:

\subsection{Define}

The first phase of DMAIC methodology is define phase. It consists of pre planning, team formation and mainly the complete description of problem. Problem definition means the voice of customer (Sharma, 2013a; Sharma \& Kadyan, 2016a; Sharma \& Kadyan, 2016b) i.e. What exactly the consumer wants and what are the deficiencies which we have to shift our focus on? The industry was running at 20644 DPMO, which after calculating the Cost of Poor Quality (COPQ) comes out to be INR 2.5 lakh per annum in monetary value. In the recent customer complaint (Table 1) a total of seven pieces were found Not Good (NG) due to mounting lug broken (Fig. 1).

\section{Table 1}

Latest Customer Complaint Report

\begin{tabular}{|c|c|c|}
\hline \multicolumn{3}{|c|}{$\begin{array}{l}\text { Problem: M10 Mounting Lug Broken } \\
\text { Product: Alternator } \\
\text { Part No: } 7006\end{array}$} \\
\hline Sr. No. & Description & Quantity/Place \\
\hline 1. & Record Date & $12 / 08 / 2015$ \\
\hline 2. & Rejection Quantity & Total 7 \\
\hline 3. & Found Area & Alternator Production Line \\
\hline 4. & Return Reason & M10 Mounting Lug Broken \\
\hline 5. & Stock: Raw Material and Assembly & Store Stock + Finished Goods $=0 / 103 \mathrm{NG}$ \\
\hline 6. & Repair or Not & Not Repaired \\
\hline
\end{tabular}

\subsection{Measure}

In this phase the extent of the problem is measured. Apart from it, a temporary corrective action was taken at the customer end which includes segregation of parts at their end and placing an extra inspection 
facility till the permanent action is taken. Table 2 shows the interim corrective action data for 3 consecutive months. A Pareto chart (Fig. 2) was prepared for finding the major causes of the rejection. The chart clearly shows the major cause of the rejection to be Fitment broken contributing approximately 53\% of the total rejection. A measurement system analysis (MSA) (Fig. 3) was also run which shows the measuring instruments were ok and in rightful condition. MSA is essential part of analysis phase as it tells about the state of measuring instrument and process followed within the organization. False measurement system can cause the good parts to get reject and NG parts to reach customer end resulting customer complaint.
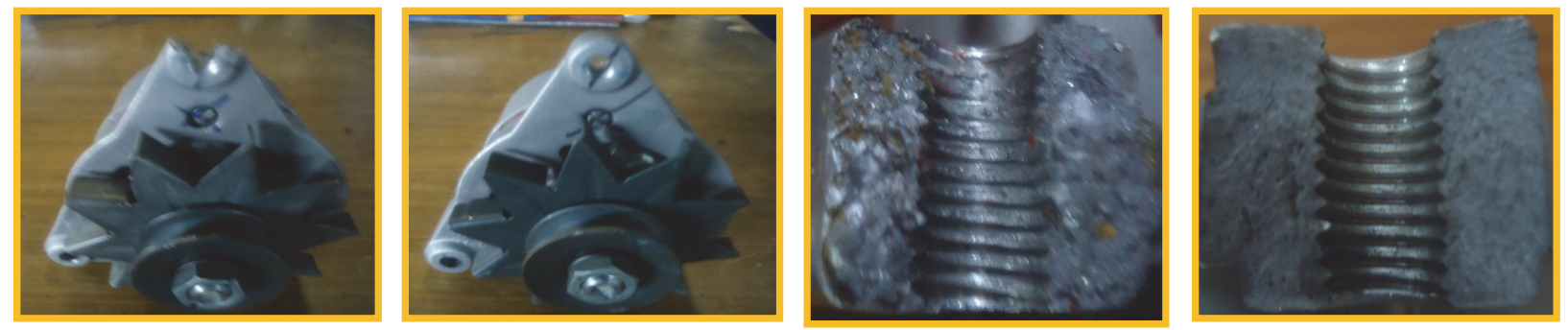

Fig. 1. NG/Good Parts and their Corresponding Grain Images

Table 2

Interim Corrective Action

\begin{tabular}{ccccc}
\hline Total Quantity & Quantity OK & Quantity Not OK & When & \%Effective \\
\hline 110 & 110 & 0 & February & $100 \%$ \\
120 & 120 & 0 & March & $100 \%$ \\
100 & 93 & 7 & April & $100 \%$ \\
\hline
\end{tabular}

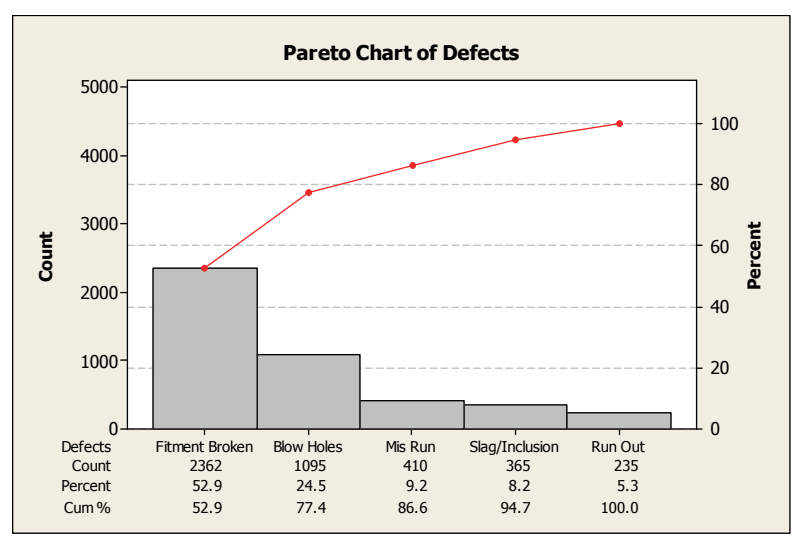

Fig. 2. Pareto Chart for Rejection

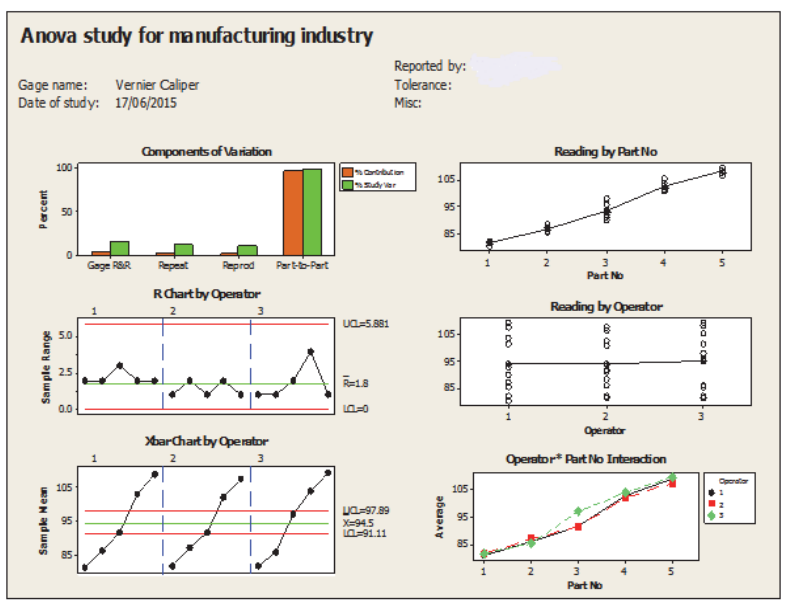

Fig. 3. Measurement System Analysis

\subsection{Analyze}

This phase is mainly concerned with in-depth analysis of manufacturing process for finding the ultimate cause of problem defined in define phase. For achieving it, first of all, a process map (Fig. 4) was generated which showed the various processes followed in manufacturing the product, highlighting the process generating (die-casting) the defect (Fig. 5). Then various statistical, for instance, fishbone diagram (Fig. 6), brainstorming (Sharma \& Kadyan, 2015a; Sharma \& Kadyan, 2015b), 5-M analysis (Table 3), why- 
why analysis and simulation were used to find the ultimate cause of mounting lug broken. Various activities that can be performed during this phase are as follows:

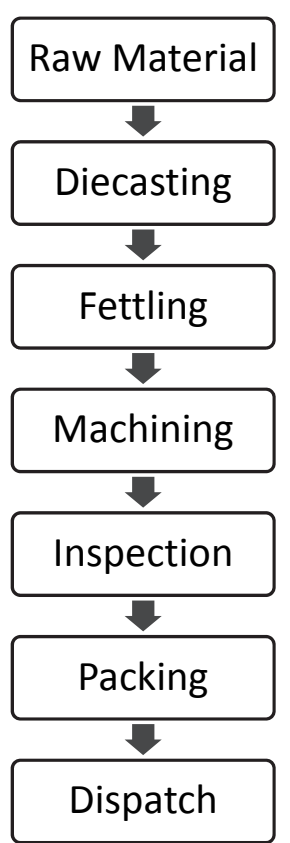

Fig. 4. Process Flow Chart
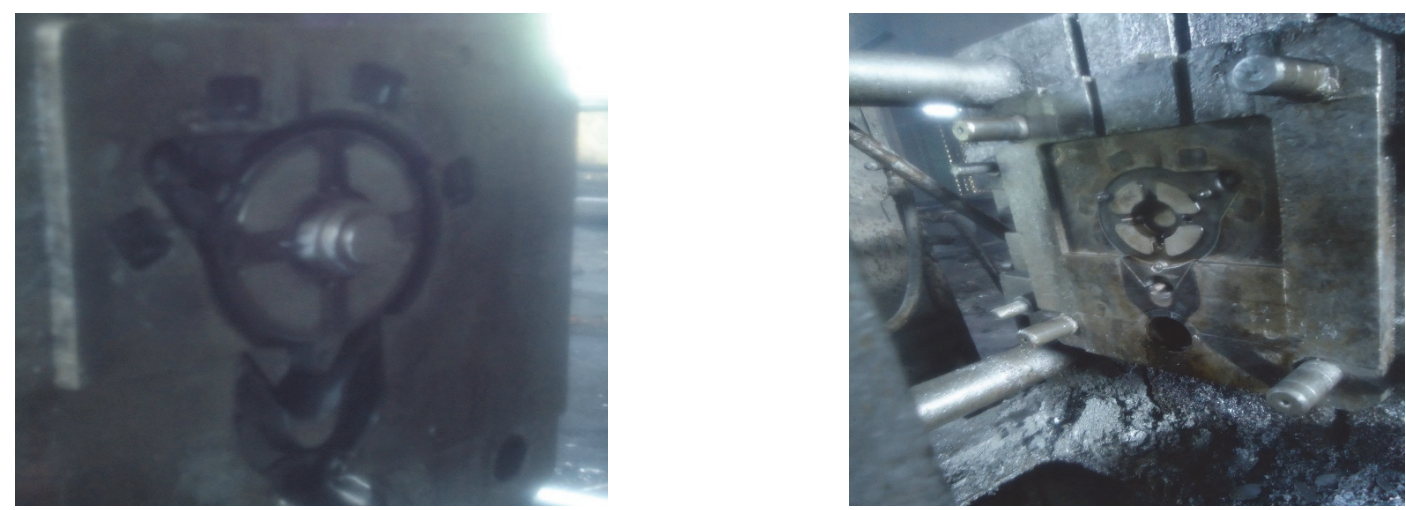

Fig. 5. Image of Die-Casting Operation

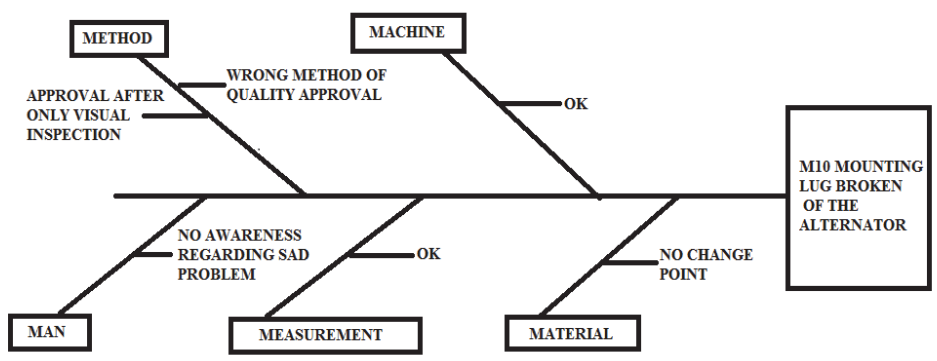

Fig. 6. Fishbone Diagram 
Table 3

5-M Analysis

\begin{tabular}{cccc}
\hline 5M & SPECIFICATION & ACTUAL & JUDGEMENT \\
\hline MAN & QUALITY APPROVAL & NO AWARENESS REGARDING APPROVAL & $\times$ \\
MEASURMENT & AS PER STANDARD & OK & $\checkmark$ \\
METHOD & APPROVAL METHOD & ONLY VISUAL INSPECTION & $\times$ \\
MATERIAL & MATERIAL AS PER & NO CHANGE POINT & $\checkmark$ \\
MACHINE & AS PER STANDARD & OK & $\checkmark$ \\
\hline
\end{tabular}

\section{Table 4}

Why-Why Analysis

\begin{tabular}{|c|c|c|c|c|}
\hline STEPS & STEP 1 & STEP 2 & STEP 3 & STEP 4 \\
\hline $\begin{array}{c}\text { OCCURRENCE } \\
\text { CAUSE }\end{array}$ & $\begin{array}{c}\text { FITMENT NOT } \\
\text { POSSIBLE AT CUS- } \\
\text { TOMER END }\end{array}$ & $\begin{array}{l}\text { M10 MUNTING } \\
\text { LUG BROKEN }\end{array}$ & $\begin{array}{l}\text { COLD SHUT OB- } \\
\text { SERVED AT THAT } \\
\text { PORTION }\end{array}$ & $\begin{array}{c}\text { SETTING PIECE } \\
\text { OF DIE CASTING } \\
\text { MIX WITH OK } \\
\text { SUPPLY }\end{array}$ \\
\hline FLOW OUT CAUSE & $\begin{array}{l}\text { WRONG METHOD } \\
\text { OF QUALITY AP- } \\
\text { PROVAL }\end{array}$ & $\begin{array}{l}\text { APPROVAL GIVEN } \\
\text { ONLY AFTER VIS- } \\
\text { UAL INSPECTION }\end{array}$ & & \\
\hline
\end{tabular}

Simulation was performed to produce same defective part so that real cause of rejection can be found out. It was carried out in three phases as follows:

Simulation 1: Low material temperature (Fig 7)

OK Condition:

1. Material Temperature: $620 \sim 660^{\circ} \mathrm{C}$

2. Die Temperature: $300 \sim 320^{\circ} \mathrm{C}$

3. Injection Pressure: $100 \sim 120 \mathrm{MPa}$

Simulation Condition:

1. Material Temperature: $600 \sim 620^{\circ} \mathrm{C}$

2. Die Temperature: $300 \sim 320^{\circ} \mathrm{C}$

3. Injection Pressure: 100 120MPa
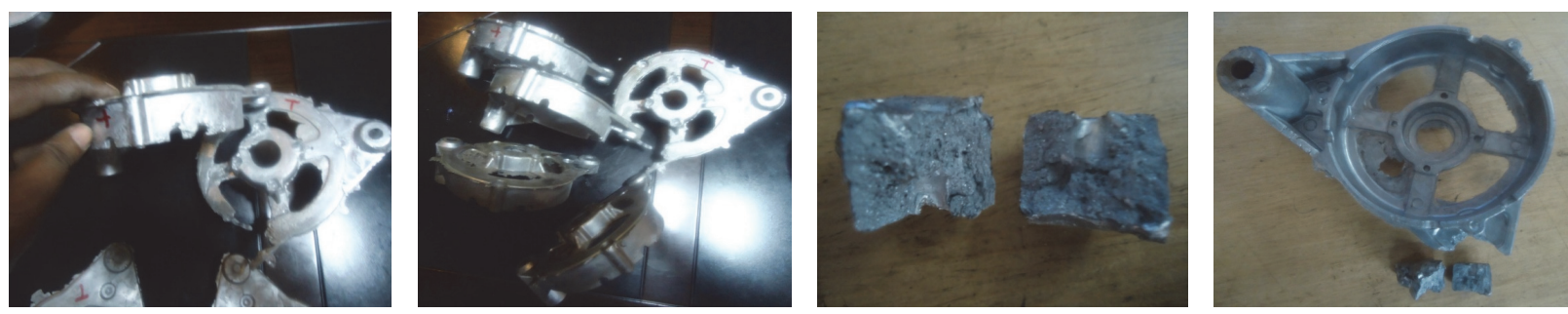

Fig. 7. Simulation 1

Conclusion:

1. Even after $25^{\text {th }}$ shots, short filling observed in pieces.

2. Not same as customer return piece.

Therefore, the machine setting used in this simulation did not specify the real cause and hence can be neglected. 
Simulation 2: Low injection pressure (Fig. 8)

Ok Condition:

1. Material Temperature: $620 \sim 660^{\circ} \mathrm{C}$

2. Die Temperature: $300 \sim 320^{\circ} \mathrm{C}$

3. Injection Pressure: $100 \sim 120 \mathrm{MPa}$

Simulation Condition:

1. Material Temperature: $620 \sim 660^{\circ} \mathrm{C}$

2. Die Temperature: $300 \sim 320^{\circ} \mathrm{C}$

3. Injection Pressure: $80 \sim 100 \mathrm{MPa}$
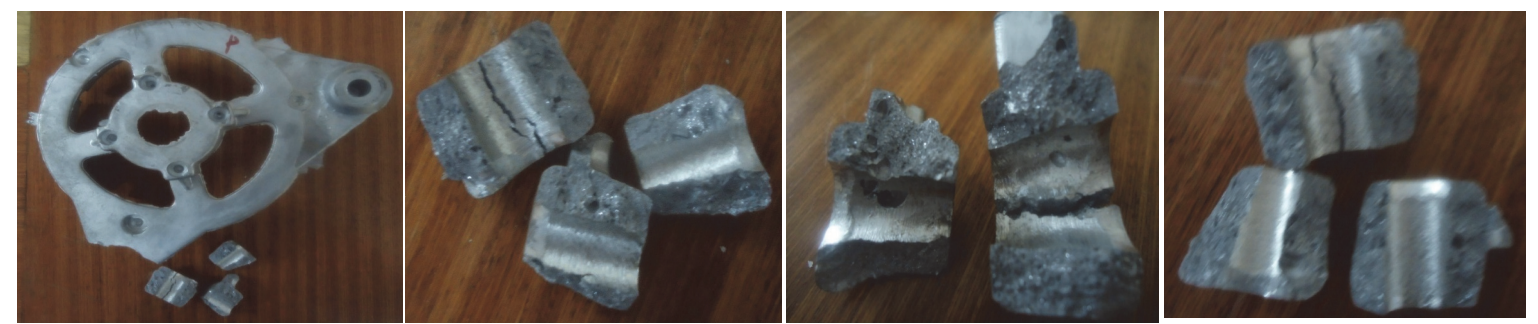

Fig. 8. Simulation 2

Conclusion:

1. Even after $25^{\text {th }}$ shots, heavy below holes and fine grain size observed.

2. Not same as customer return piece.

Therefore, the machine setting used in this simulation too did not specify the real cause and hence can be neglected.

Simulation 2: Low die temperature/initial shots (Fig. 9)

Ok Condition:

1. Material Temperature: $620 \sim 660^{\circ} \mathrm{C}$

2. Die Temperature: $300 \sim 320^{\circ} \mathrm{C}$

3. Injection Pressure: 100 120MPa

Simulation Condition:

1. Material Temperature: $620 \sim 660^{\circ} \mathrm{C}$

2. Die Temperature: Normal Process

3. Injection Pressure: $100 \sim 120 \mathrm{MPa}$

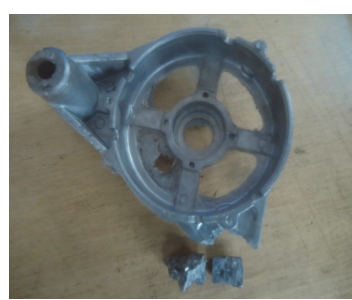

$20^{\text {th }}$ No. of Piece

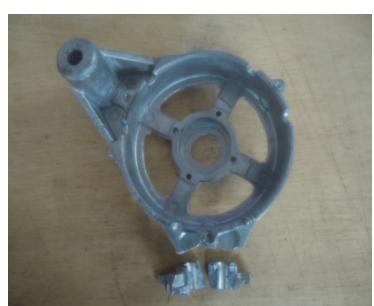

$25^{\text {th }}$ No. of Piece

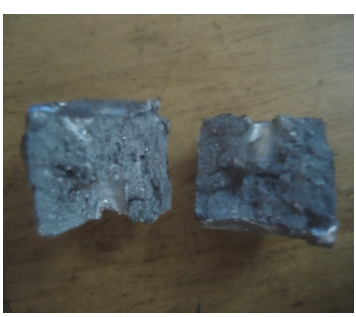

$20^{\text {th }}$ No. of Piece

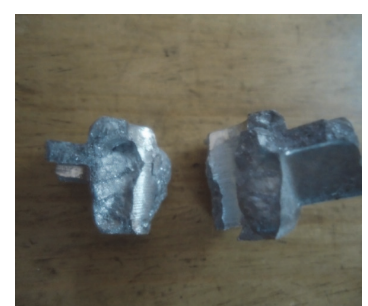

$25^{\text {th }}$ No. of Piece

Fig. 9. Simulation 3 
Conclusion:

1. After $20^{\text {th }} \& 25^{\text {th }}$ Shots, Disputed grain size observed.

2. Same as customer return piece.

Therefore, the machine setting used in this simulation matches with the real cause and hence needs correction.

Simulation 3: Low die temperature/final shots (Fig. 10)

In this case we have the following

1. Material Temperature: $620 \sim 660^{\circ} \mathrm{C}$

2. Die Temperature: $300 \sim 320^{\circ} \mathrm{C}$

3. Injection Pressure: $100 \sim 120 \mathrm{MPa}$
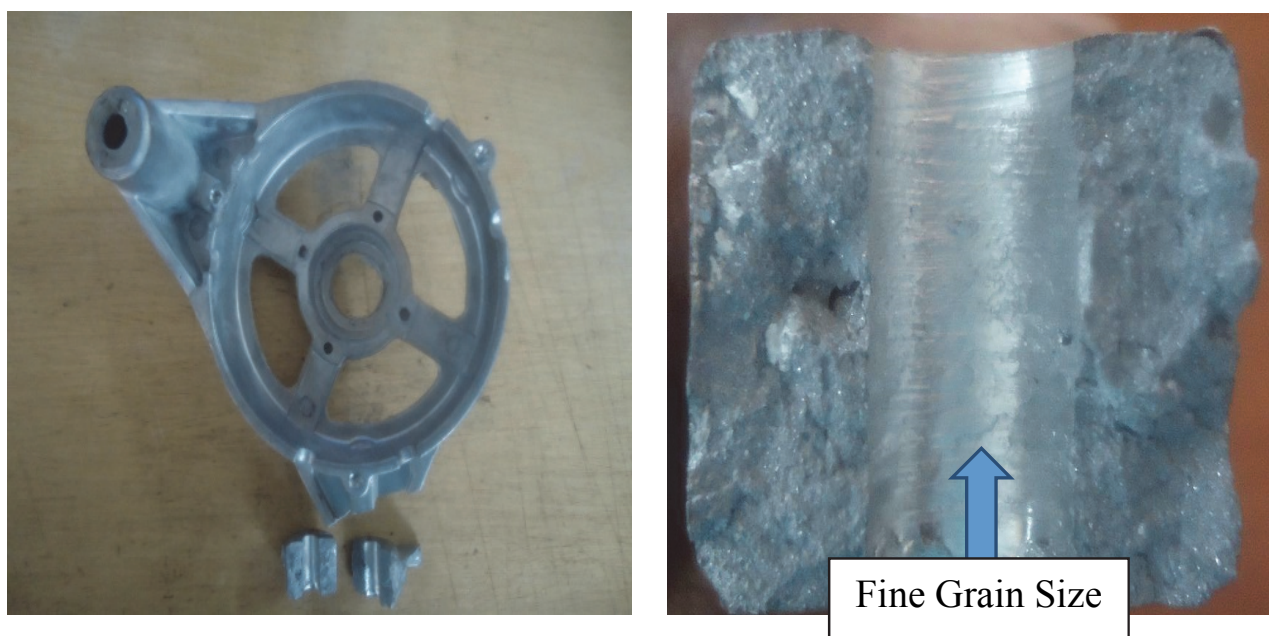

Fig. 10. Ok Condition Part

Therefore:

1. After $26^{\text {th }}$ Shots fine grain size observed.

2. Same as Ok condition.

Now the machine setting was freeze as mentioned above in Ok conditioned part and also documented in the control plan of the part to eliminate any future ambiguity.

\subsection{Improve}

In this phase, in accordance to the root causes found out in analysis phase, corrective action was planned and implemented (Sharma, 2017b; Sharma, 2013c). First of all, a training for all concerned employees was arranged to detail them about the problem and remedial actions. Then a risk assessment and Failure Mode Effect Analysis (FMEA) was performed. Machines settings were changed in all concerned documents. New bracket has been changed in alternator assembly. The all casting process should be changed permanently according to root cause analysis. All temperature and pressure parameter will be fixed according to root cause to prevent the further problems and remove problems permanently. Quality department was made responsible for implementing and validating the permanent corrective action and Research \& Development (R \& D) department removed the containment action plan for permanent changes. 
Table 5 shows the various measures and their corresponding status. Table 6 depicts the documentation change measures and corresponding status.

\section{Table 5}

Status of Various Measures

\begin{tabular}{lll}
\hline OCCURE ACTION & WHO & STAUTS \\
\hline Change the material temperature & Furnace operator & OK \\
Change the injection pressure & Injection molding machine operator & OK \\
Change quality approval method & Quality department & OK \\
Aware the worker about problem & Cross functional team (CFT) & OK
\end{tabular}

\section{Table 6}

Documentation Change Status

\begin{tabular}{lll}
\hline IMPEMENTATION & ACTION & RESPONSIBILITY \\
\hline DFMEA & No changed & R\&D \\
Drawing & No changed & R\&D \\
Part Inspection Standard & Changed & CFT \\
PFMEA & No changed & Process Engineer \\
Control Plan & Changed & CFT \\
Process Instruction & Given & Process Engineer \\
Training Matrix & Given & Process Engineer \\
\hline
\end{tabular}

After successful implantation of corrective actions, the PPM levels was drastically reduced to $2.68 \mathrm{ppm}$ which was a huge achievement for the industry of this level. PPM improvement also brought financial gains which in turn motivated the industry to implement similar projects in various other sections.

Table 7

Review Status

\begin{tabular}{lll}
\hline Review \& update system/procedures & Action & Responsibility \\
\hline All Document & $\begin{array}{l}\text { All the related documents have al- } \\
\text { ready been changed }\end{array}$ & CFT \\
\hline
\end{tabular}

\subsection{Control}

In this phase, steps are taken to prevent the recurrence of the cause of rejection (Kaushik et al., 2008). The changes made in the process were assessed and monitor. Also, an opportunity was given to team for preserving the status and share the knowledge acquired during project to management and colleagues. In present study, the process is still under monitoring. Although a review of the status change has been performed (Table 7). After the completion of this phase, similar processes and products will be reviewed and if needed corrections will be made. Further, special procedures and work instructions will be developed. A special training program will be executed for all operators. All in all, it will be try out to make it as an organizational culture. 


\section{Conclusion}

The prime motive of this case study was dissecting problem and solving it in industrial environment by implementing six-sigma DMAIC methodology and acquiring desired results working in a team. Adequate persuasion of corrective actions brought down the rejection levels from $20664 \mathrm{ppm}$ to $2.68 \mathrm{ppm}$. This undoubtedly was a great accomplishment. The case study also brought financial gains. A cost benefits of 2.5 lakhs per annum were achieved. Talking about intangible benefits organization was able to achieve employee motivation, personal development, competitiveness, sense of team work and much similar project initiations. Authors encourage similar implementations to enhance the productivity levels of small scale industries.

\section{References}

Edgeman, R. L., \& Dugan, J. P. (2008). Six Sigma from products to pollution to people. Total Quality Management, 19(1-2), 1-9.

Falcón, R. G., Alonso, D. V., Fernández, L. G., \& Pérez-Lombard, L. (2012). Improving energy efficiency in a naphtha reforming plant using Six Sigma methodology. Fuel processing technology, 103, 110-116.

Ho, S. K. (2010). Integrated lean TQM model for sustainable development. The TQM Journal, 22(6), 583-593.

Kaushik, P., Grewal, C. S., Bilga, P. S., \& Khanduja, D. (2008). Utilising Six Sigma for energy conservation: a process industry case study. International Journal of Six Sigma and Competitive Advantage, 4(1), 18-34.

Kaushik, P., Dahiya, V., \& Mittal, K. (2017). Statistics for industries: A sophisticated approach. Management Science Letters, 7(8), 397-406.

Kaushik, P., \& Mittal, K. (2015a). A general model for problem solving in manufacturing or service organizations. Journal of Engineering and Technology, 0 (0), 0. http://doi. org/10.4103/09768580.158566 .

Kaushik, P., \& Mittal, K. (2015). Significance of Six Sigma Basics in a Manufacturing Unit: A Case Study.". Progress in Management Sciences, 3(1).

Kaushik, P., Mittal, K., \& Rana, P. (2016). Energy paybacks of six-sigma: A case study of manufacturing industry in India. Management Science Letters, 6(11), 691-700.

Kaushik, P., Prikshit \& Mittal, K. (2016). Gratitude of six-sigma: A case study of manufacturing environment Prabhakar. Journal of Mechanical Engineering, 126, 223-231.

Mittal, K., Chandra Tewari, P., Khanduja, D., \& Kaushik, P. (2016). Application of Fuzzy TOPSIS MADM approach in ranking \& underlining the problems of plywood industry in India. Cogent Engineering, 3(1), 1155839.

Mittal, K., \& Kaushik, P. (2011). Quality function deployment: A way to total quality. Yamuna Journal of Business Management \& Technology, 1(1), 11-18.

Mittal, K., Kaushik, P. \& Khanduja, D. (2010). APQP-A management stream. Ishan Management Stream, 1(11), 05-07.

Mittal, K., Kaushik, P., \& Khanduja, D. (2012). Evidence of APQP in quality improvement: An SME case study. International Journal of Management Science and Engineering Management, 7(1), 20-28.

Mittal, K., Khanduja, D. \& Kaushik, P. (2010). ABQP: Ladder to Success. SCMS Journal of Indian Management, 7(4), 87-92.

Mittal, K., Khanduja, D. \& Kaushik, P. (2011). Leveraging APQP methodology to drive improvement in SME : A case study. International Journal of Contemporary Practices, 1(1), 38-51.

Mittal, K., Khanduja, D. \& Tewari, P.C. (2017). An Insight into "Decision Tree Analysis ." World Wide Journal of Multidisciplinary Research and Development, 3(12), 111-115.

Mittal, K. \& Prajapati, R.K. (2014). Quality councils: An overview. International Journal of Management, IT and Engineering, 4(12), 200-211.

Mittal, K., Tewari, P.C. \& Khanduja, D. (2017a). On the right approach to selecting a quality improvement project in manufacturing industries. Operation Research and Decisions, 27(1), pp.105- 
124.

Mittal, K., Tewari, P. C., \& Khanduja, D. (2017b). Productivity improvement under manufacturing environment using Shainin system and fuzzy analytical hierarchy process: a case study. The International Journal of Advanced Manufacturing Technology, 92(1-4), 407-421.

Mittal, K., Tewari, P.C. \& Khanduja, D. (2016). Refurbishing business processes: An insight. Journal of Industrial Engineering and Advances, 1(1), 1-8.

Sharma, C. (2013a). Begining of diverse quality management methodologies in libraries:An outline. International Journal of Management, IT and Engineering, 3(8), 322-346.

Sharma, C. (2017a). Initiating and linking total quality management in libraries. World Wide Journal of Multidisciplinary Research and Development, 3(10), 119-122.

Sharma, C. (2017b). Momentous of TQM principles in libraries: An overview. Journal of Emerging Technologies and Innovative Research (JETIR), 4(10), 172-176.

Sharma, C. (2013b). Quality management in libraries: An outline. International Journal of Enhanced Research in Management \& Computer Application, 2(8), 1-4.

Sharma, C. (2017c). Quality management in relation with library services. International Journal of Research in Engineering, IT and Social Sciences, 7(10), 11-14.

Sharma, C. (2012). Six sigma reflections in the direction of librarie: An organization outlook. International Journal of Management, IT and Engineering, 2(12), 521-528.

Sharma, C. (2013c). Total quality management essentials in libraries. Academic Discourse, 2(2), 94-97.

Sharma, C. \& Kadyan, S. (2015a). Analyzing quality management move towards quality service in libraries. Research Journal of Library Sciences, 3(4), 8-11.

Sharma, C. \& Kadyan, S. (2016a). Examine total quality management in engineering college libraries : An evaluative study. Pearl-I Journal of Library and Information Science, 10(4), 215-223.

Sharma, C. \& Kadyan, S. (2015b). Performance evaluation through quality index model: A case study of an institute library. International Research: Journal of Library \& Information Science, 5(4), 625-641.

Sharma, C. \& Kadyan, S. (2016b). Road plan to enterprise TQM from manufacturing to library services. International Journal of Information Dissemination and Technology, 6(3), 165-169.

Srinivasan, K., Muthu, S., Devadasan, S. R., \& Sugumaran, C. (2016). Six Sigma through DMAIC phases: a literature review. International Journal of Productivity and Quality Management, 17(2), 236-257.

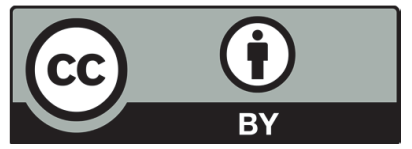

(C) 2018 by the authors; licensee Growing Science, Canada. This is an open access article distributed under the terms and conditions of the Creative Commons Attribution (CCBY) license (http://creativecommons.org/licenses/by/4.0/). 